УДК 811.163.41(091)

811.163.41 Караџић В. С.

https://doi.org/10.18485/msc50.2021.2.ch1

\title{
Павле Ивић
}

\section{ВУК КАРАЏИЋ И КЊИЖЕВНИ ЈЕЗИК КОД СРБА}

Тема овог прилога обавезује нас да прво посветимо пажњу једном крупном, а засад недовољно расправљеном питању: који је то језички тип истиснут Вуковом победом из функције књижевног језика Срба? Сви знамо да је Вукова заслуга што је стари књижевни језик замењен новим, али о томе шта у овом случају конкретно значи израз „стари језик” владају погрешне представе. У публици живи уверење, које обично ни стручњаци не оспоравају, да је то био хибридни, макаронски „славеносрпски” језик, та произвољна и хаотична мешавина трију елемената српског народног, црквенословенског руске редакције и руског књижевног језика. То се уверење поткрепљује и чињеницом да је Вук у својим раним радовима речито доказивао да том језику нема места у српској књижевности. Па ипак, ако приђемо ближе чињеницама, показује се да распрострањено уверење напросто није тачно. Вук није прогнао из књижевне употребе тај језик, већ један други.

Осврнимо се за тренутак на генезу и судбину славеносрпског језика. Настао је у другој половини XVIII века као резултат покушаја појединих српских писаца - пре свега Захарије Орфелина - да помире идеал и стварност. Идеал је био рускословенски црквени језик, понекад и тадашњи руски књижевни језик, а стварност - живи штокавски говор српског народа. Рускословенски је у оно време био не само богослужбени, већ и административни језик српске православне цркве. На његовој страни налазила се, осим угледа и моћи те организације, и распрострањена заблуда да је то у ствари стари српски језик, и да се његовом употребом Срби враћају својим коренима. Руски књижевни језик се у XVIII веку брзо развијао и постајао све савршенији инструмент израза. Био је то језик једине словенске државе и једине православне, а велике, чак, огромне, и моћне и славне. Државе у коју су упирали погледе пуне неке ирационалне наде Срби распети између турске и аустријске владавине, укљештени између две туђе вере и два туђа језика, подвлашћени и 
поробљени, презрени, притиснути свешћу о недовољности својих снага, у сваком погледу. Осим тога и црквени и руски језик имали су, као оруђа културне комуникације, недостижне предности. Речи за појмове апстрактније и истанчаније, као и речи за све оно што је сачињавало тадашњу цивилизацију, нису постојале у српском народном говору, али су се могле наћи у црквенословенском и у руском књижевном језику. Али, на невољу, те језике је мало ко међу Србима знао како треба. Писци су почели схватати да би писати црквеним или руским језиком значило осудити своје дело на нечитање, као што би с друге стране писати народним језиком о већини тема било немогуће јер је недостајала лексика за све значењске области изван свакодневног живота необразованих људи. Уосталом, многим васпитаницима столећа просвећености писање језиком управо тих људи могло је изгледати недостојно просвећеног списатеља. У народном језику се и иначе често гледао жалосни плод кварења старог српског, тј. рускословенског језика. Излаз из тога процепа нађен је у стварању компромисног „средњег стила”, „гражданског језика” који је тако свесрдно бранио Теодор Јанковић Миријевски у свом знаменитом меморандуму аустријским властима 1782. године. Поверовало се да је створен језик који ће бити разумљив масама српског народа, али ће ипак бити оплемењен, издигнут изнад њиховог простачког говора.

Људи који су стварали славеносрпски језик нису били језикословци нити су умели повући границу између неопходног попуњавања речничког фонда књижевног језика и механичког преузимања свега и свачега из неког туђег језика. Уосталом, њихов однос према језицима-узорима није био првенствено утилитаран. Они су се пре свега поводили за престижем тих језика, а престиж се тицао свега: не само вокабулара, већ и гласова, облика, синтаксе. Сам митрополит Стефан Стратимировић замерио је Вуку што у тексту народне песме није ставио стараго место старога. Као да је веровао да у томе стараго има нечег лепшег, узвишенијег, или можда српскијег.

Идиом који се добио укрштањем није био рационални спој елемената из разних извора, већ мешавина у којој је место сваког елемента српскохрватског језика могао доћи одговарајући елемент црквеног или руског језика. Овде треба подвући: и руског, и нарочито руског, јер је тадашња цивилизацијска стварност захтевала и многе изразе каквих није било у црквенословенском језику. Није случај што међу безбројним лексичким „славенизмима” из те епохе има много таквих којих нема у црквенословенском, а мало таквих којих нема (одн. тада их није било) у руском језику, - наравно, уз мноштво лексема заједничких тим двама језицима. 
Славеносрпски није био прави језички систем, јер се тим именом не може назвати језички конгломерат без одређеног лика, такорећи сав састављен од дублета, чије је главно правило било „може и овако и онако”. На први поглед би се рекло да је такво стање нудило изванредно богате могућности изражавања: извори трију језика били су широм отворени српском писцу - наравно, ако је био довољно јак да из њих црпе (узгред да напоменем, то је успело, и то на величанствен начин, само једном писцу, додуше из знатно позније епохе и носиоцу друкчијих књижевнојезичких погледа - Његошу). У пракси се обично све сводило на произвољност и лутање. Вук је то сликовито описао: „Што не знаш Српски, метни Славенски; што не знаш Славенски, метни Српски; а што не знаш ни Српски ни Славенски, метни како ти драго (што ти прије на ум падне); ђе се из два језика (и из треће главе) по својој вољи трећи гради, ту се не може погријешити" (Предговор Рјечнику из 1818, стр. VI). Било је и повода за забуну. Многе речи, такве као брег, живот, зној, образ, палаи, памет, реч, слово, част, чест, бистар, вредан, красан, хитар, просити имају једно значење у српском, а друго у црквенословенском или руском. Како онда употребити такву реч? Мудрост понекад налаже: никако. Заобићи двосмислени израз може бити једини начин да се избегну неспоразуми. Тако се преобиље претвара у сиромаштво. Никад код Срба није било толико језичке несигурности и колебања као у славеносрпско доба. Наравно, о неком истанчаном стилу није могло бити ни говора. Њега нема без јасно прецизираних значењских нијанса речи и обрта, а у сусрету сродних језика сваки пут се показује да већина заједничких речи има значења донекле или отприлике једнака. Уза све то, славеносрпски ипак није увек постизао ни онај основни циљ, да буде разумљив ширим слојевима српског народа.

Године 1783. Доситеј Обрадовић је одлучно иступио за народни језик у књижевности: „... кад учени људи мисли своје на општему целога народа језику пишу, онда просвештеније разума и свет ученија не остаје само при онима, који разумевају стари књижевни језик, но простире се и достиже до сељана; преподавајући се најпростијему народу и чобаном само ако знаду читати." Доситејево залагање и данас се често помиње, како у науци тако и у школским уџбеницима и популарним написима, додуше обично уз ограду да он, због свог црквеног образовања и дугог странствовања, није добро знао писати народним језиком. У тој огради има само део истине, и то мањи део. Тачније је рећи да је он писао народним језиком, али се није устезао да црквенословенским или руским речима искаже појмове за које народни језик није имао свога израза. Само по изузетку њему се догађало да унесе славенизам и тамо где се мисао 
могла изразити и без њега. Са Доситејем такав је народни језик закорачио у књижевност, са његовим следбеницима наставио да живи у њој.

У последњим двема деценијама осамнаестог века у српској књижевности су коегзистирала чак четири језика: црквенословенски, славеносрпски, народни и руски „историографски стил”. Овај последњи није, у активној употреби, доживео смену столећа, а црквенословенским, ван црквених књига и уџбеника за основне школе, ретко се писало. Јасно су се издвојила два главна ривала: славеносрпски и доситејевски народни. С временом је народни језик освајао све више простора. У текућој књижној продукцији растао је удео књига на том језику, а и у самом славеносрпском јачала је српска компонента, потискујући славенску. Понекад није једноставно одредити да ли је језик неког дела „народни” или славеносрпски. И сама произвољност славеносрпског језика почињала се смањивати: појавиле су се граматичке и гласовне категорије у којима се усталило једно или друго решење.

У другој деценији 19. века два писца који нису били доситејевци задали су озбиљне ударце славеносрпском језику. Учени архимандрит Павле Кенгелац, ватрени поборник црквеног језика у књижевности, извргао је руглу 1811. у предговору Јестествословија несређеност славеносрпског језика: „Вси народи, и сами јазичници книги своја по граматијским правилам списаша, у нас по правилам баби Смиљани пишутсја.” Са супротних позиција критиковао је славеносрпски језик и списатеље који њиме пишу Вук Караџић у својој рецензији Милована Видаковића 1817. и у Предговору Сриском рјечнику 1818. године. Вук се жестоко оборио на произвољност и хаотичност хибридног језика, а и на бесмисао самог настојања да се књижевни језик удаљи од народног.

Током двадесетих година XIX века углавном се угасила употреба црквенословенског језика ван цркве, а такође и славеносрпског. После средине те деценије тим језицима ће писати, спорадично, понеки од аутора који су се одраније бавили књижевношћу, а неће им се придружити ниједно ново име. Томе је свакако знатно допринео и Вук Караџић, не само својим полемикама, него и речником и издањима народних песама. Ипак, било би погрешно гледати у извршеној промени претежно Вуково дело. Њени корени били су дубоки, а Вук тада још није био призната величина чија би реч била пресудна.

Околности које су довеле до усвајања рускословенског језика и појаве славеносрпског у XVIII веку сад више нису биле актуелне. Црква више није била једина установа и упориште српског народа, једино културно и политичко средиште. Разгранавало се и постепено лаицизирало школство, а почев од 1826. Срби су имали своју Матицу. Јужно од Саве и Дуна- 
ва израстала је обновљена српска држава. Водећа друштвена снага међу Србима у Хабсбуршкој монархији сад је било све бројније и све богатије грађанство, док је у ослобођеној Србији доминирало сељаштво, тачније народни поглавари који су се почели издвајати из сељачке масе. Новоизрасли носиоци друштвене и економске моћи природно су тежили дасвој положај учврсте писменошћу и знањима. У њиховом је интересу било да се књижевни језик ослободи излишних препрека које су њима отежавале приступ књизи. Међу писцима су сада увелико преовлађивали световњаци, удео свештених лица битно се смањио. Напредак је био очигледан, и на политичком и на привредном и на културном пољу. У таквим приликама будили су се национална самосвест и оптимизам. Више није било разлога за очајање, ни за оно панично осећање угрожености које је у своје време гонило српску јерархију у наручје Русији. Културна окренутост ка тој далекој земљи, чији се језик није могао чути у српским крајевима нити се могао учити у српским школама, уступила је место европској оријентацији, првенствено ка немачкој култури. Немачки језик био је у хабсбуршком царству неопходан услов друштвеног успеха, а немачка књижевност била је на врхунцу процвата. Немачке књиге су се међу Србима много читале, а и српских је бивало све више, те су руске постајале све мање потребне. Непосредно ослањање у књижевности на један страни језик, макар и сродан, много је лакше остварљиво док списатељи, и уопште писмени људи, сачињавају узан круг просвећених. Сa ширењем просвете нормално иде враћање домаћим коренима.

У двадесетим годинама XIX века ступило је на позорницу српске књижевности поколење интелектуалаца солидније образованих него већина дотадашњих српских писаца. Ти млади људи, међу којима су били Георгије Магарашевић (р. 1793), Јован Хаџић (1799), Јован Стејић (1803) и Јован Стерија Поповић (1806), сматрали су природним да књижевни језик Срба буде стварно српски. Ако од Доситеја почиње шира ynотреба народног језика у новијој српској књижевности, с овом генерацијом почиње његова владавина. Ти су људи били не само брзо запажени као књижевни посленици, већ су постали утицајни чиниоци у култури свог народа. Један од њих, Магарашевић, био је први уредник Летопи$c a$, тада јединог српског часописа. Други, Хаџић, наследио је Магарашевића у тој функцији. И остала двојица јављају се као сарадници Летописа у његовим првим бројевима. Језик тих писаца био је модернизован доситејевски. Гласови и морфологија били су штокавски, основни речнички фонд такође, док су у „горњем” слоју лексике, цивилизацијском и терминолошком, господарили славенизми, што практично значи претежно речи присутне у тадашњем руском књижевном језику. Укратко, 
славенизми су у том језику по правилу остајали на нивоу лексичких позајмљеница. Нестало је оног огромног простора за дублетне опције, сад се углавном знало који се елементи узимају из једног извора, а који из других. Са гледишта типологије књижевних језика, том се идиому приближава данашњи бугарски књижевни језик.

У текстовима на језицима описаног устројства размера између домаће и преузете лексике зависи од теме. Нека ту чињеницу илуструју два узорка, оба из Летописа и из пера његовог првог уредника Магарашевића. На стр. 145 четврте свеске (прве за годину 1826) читамо: „Господин К(опитар) пролази кроз све три части народни српски песама са њему својственим остроумијем и основаним вјежеством, опшчеполезна своја примјечанија читатељу предлагајући." Предмет излагања је литераран и апстрактан. Од укупно седам заједничких именица четири имају изразита црквенословенска (истовремено и руска) гласовна и/или творбена обележја, једна (читатељь) је позајмљеница из руског која се боље уклапа у структуру српскохрватског језика, а само две (господин и песма) могу се сматрати домаћим речима. Од трију придева један (опшчеполезна) неадаптиран је русизам, други (својственим) спада у русизме који нису у сукобу са структуралним одликама домаћег језика, а само један (народни) припада и аутохтоној лексици. Глагол предлагајући и партицип основаним такође су преузети из руског, али без гласовних обележја која би била туђа српскохрватском језику. Међутим, на стр. 86-87 осме свеске Летописа (III/1, 1827) налазимо, у препричавању једне народне песме: „Ту се договоре, да једног от његови сродника, који је млад и леп био, под његовим именом и његовим оделом за младожењу издаду." Овде нема апстрактних појмова, па ни елемената туђих народном језику, с јединим изузетком om место oд, што ће пре бити правописна него гласовна појава.

Народни језик који је преовладао у српској књижевности у двадесетим годинама XIX века разликовао се од језика Вукових списа у два правца.

Иако је у својим првим делима употребљавао славенизме из „горњег” слоја лексике, Вук је убрзо напустио ту праксу. Требало му је мање од деценије да се усаврши у умећу „посрбљавања” славенизама које у писању није могао заобићи. Мењао је гласовни склоп речи тако да сви рефлекси прасловенских фонема буду штокавски, а да суфикси одговарају домаћим творбеним моделима. Ликове као пророчество или человјекољубије претварао је у такве као пророштво и човјекољуббее. Тако преправљене, лексеме су изгледале као да су настале на српском тлу. Уклањани су трагови страног порекла, не само они који нарушавају правила структуре српскохрватског језика, него и они који указују на 
гласовни развој друкчији од домаћег, а видљиви су само за филолога. Путоказе за изгон, односно за прилагођавање славенизама садржала је Вукова расправа из 1826. о разликама између језика „славенскога и српског”, па и она из 1828. о деривационим наставцима у српском језику, дакле о оним легитимним, које треба задржати у језику, за разлику од суфикса-уљеза.

Вуков језик се у оновременој српској књижевности издвајао и друкчијом дијалекатском бојом. Владајућем војвођанском дијалекту он је супротстављао свој „ерцеговачки”, додуше у знатно прилагођеној верзији. Три су слоја измена уграђена у основицу јекавског књижевног језика какав познајемо данас. Неколико изразитих херцеговачких особености које су Вукови преци пренели из своје дурмиторске постојбине у Тршић ишчезло је током живота двају поколења у Тршићу. Неке појединости свог родног говора напустио је Вук онда кад је почињао писати, свакако зато што му је изгледало да нису прикладне за књижевни језик. И најзад, Вуково увођење $x$ 1836. године и писања тje, дje у примерима као mjeрати, дјед 1839, заједно с неким ситнијим интервенцијама које су ишле у истом смислу, сведоче о његовом будном настојању да свом језику да наддијалекатска, што шире прихватљива обележја. Што се тиче књижевног језика на војвођанској основи, он засад није проучен - управо се завршава једна дисертација о њему, а друга је у припреми - али се на основу увида у текстове може одлучно рећи да се и тај језик био ослободио најизразитијих дијалектизама. Војвођански месни говори се знатно разликују међу собом, а у књижевном језику су се лакше одомаћивале црте говора ближих штокавском просеку, што је, уосталом, погодовало безболном усвајању тог језика у ослобођеној Србији. Тако су се један наспрам другога нашли ублажени херцеговачки говор и исто тако ублажен војвођански. У двадесетим годинама та је неподударност била, квантитативно мерена, много мање изразита од оне коју су стварали употреба односно избегавање славенизама. Стога је немогуће изабрати кратак одломак у којем би се манифестовао већи број разлика. Да би се појава илустровала, потребно је прегледати релативно дужи текст. Осврнућемо се, за ову прилику, на Магарашевићев адаптирани превод Гримовог предговора Вуковој граматици, и то на одломке штампане у свескама 2 (1825) и 4 (1826) Летописа, укупно двадесетак страница мањег формата. Од облика који на дијалекатској релацији контрастирају с Вуковим језиком ту налазимо: живили св. 2, стр. 89, гди 90, диви (= дивљих) 91, сломије 91, трпити 92, 95, свију 92, 93, 100, у побочнима стварма 95, под гречески епископи 95, со тим 97, у върнима преписи 98, у неки комитати 100, по језищи Лпл 100, нигди св. 4, стр. 102, со тим 102, 105, 106, волели 102, гди 
103, у усти 103, у Карловци 109. Овоме, наравно, треба додати разлику између екавице и јекавице. Међутим, тај је контраст осетно умањен тиме што је Магарашевић, као и већина других српских писаца његовог времена, по правилу писао слово $z$ место екавског рефлекса старог јата, a то се слово могло читати и на јекавски начин, као што се и читало у славенизмима.

Упркос далеко већој фреквенцији разлика у погледу славенизама, и упркос чињеници да су практично једино оне могле понекад угрозити разумљивост текста, дијалекатска неподударност се нипошто не сме потцењивати. Са гледишта групне психологије дијалекатски идентитет је необично важан; за њега се везују многе осетљивости. У тој светлости лако се схвата жестоко противљење на које је наилазило Вуково јекавско писање, а и сама Вукова приврженост завичајном говору, упркос свим тешкоћама које му је она стварала. Магарашевић и његови истомишљеници често су наглашавали да је борба око књижевног језика завршена у корист народног, одајући при том признање Доситеју као покретачу те борбе. Вук, међутим, није обуставио своје борење. За њега, очигледно, владајући књижевни језик није био народни, или бар није то био у довољној мери. Читајући Вукове списе чак не добијамо утисак да се у међувремену нешто битно променило. Он је и даље нападао употребу славенизама, и то, рекло би се, сада са више успеха. Свакако и под његовим утицајем - или због страха од његове критике - у делима књижевника такве речи су се почеле проређивати. Додуше, језик администрације, све разгранатије и све утицајније, врвео је од израза као началство, високопочитајеми, торжествено, движеније, набъудавати, преизрјадни. Кад је Друштво српске словесности пришло планском раду на терминологији и обнародовало спискове новосачињених термина из разних струка, Вук се успротивио тој иницијативи тврдећи да чланови Друштва не познају довољно законитости српског језика, па би ауторитет Друштва у том тренутку подупро лоше сковане изразе. Поткрепивши то гледиште упечатљивим примерима, он је 1845. постигао да Друштво обустави започети посао.

Несмањеном жестином, Вук је и даље критиковао „погрјешке” у језику, махом дијалектизме североисточних српских крајева. Понављајући своје тврђење да се нигде не говори српски тако лоше као у тим пределима, он као да је желео дискредитовати тадашњи екавски књижевни језик. Истовремено, он је дао ново и потпуније образложење због чега је боље писати јекавски него екавски.

Вуков превод Новог завета, објављен 1847, био је замишљен као образац новог књижевног језика и као доказ да је он кадар да искаже и сло- 
жени, често апстрактни садржај Библије. Наравно, при том се лексички фонд народног говора показао недовољним. Вук је магистрално решио проблеме који су из тога произашли. Знатан број речи, таквих као зборница, отпад или виноградар, он је сковао у духу народног језика, а друге, као преступник или животни, преузео је из црквенословенског. Тамо где су се такве речи сукобљавале с творбеном структуром или са законима гласовног развоја српскохрватског језика, он их је посрбљавао. Пут је био показан и Срби су спремно пошли њиме. Сада је Вук био највећи ауторитет у свом народу, идол романтичарски настројене и егзалтирано родољубиве школоване омладине. Вуково фактографско објашњење примењених поступака у предговору Новог завјета претворило се у упутство за акцију филолога и писаца.

Све што је Вук предлагао добро се уклапало у језик. Српска реченица је постала лакша и спретнија кад су речи као просвјешченије, опстојателство, пожелателно или поњатије замењене таквима као просв(j)ета, околност, пожельо, појам. Тиме је постизан склад између елемената језичког система. Тако је облик совершен преправљен у савршен, са префиксом са- који и иначе постоји у језику у речима као савити или саплести и са коренском морфемом ври- која постоји у довриити, свршити. Именицу чувство истисло је осећаюе. Глагол чути у новијем српскохрватском обично не значи „осећати”, а ни изведеница на -вство од таквог глагола не одговара творбеним правилима. Отуда чувство није имало ослонца у језичком систему. Сасвим логично, термин је сад изведен од глагола осећати, живог у употреби. Поготову се осећајан боље уклапа у језичку структуру него чувствителан. Придев хитар у значењу „лукав” избачен је из употребе јер се сукобљавао са домаћим хитар „брз, покретљив”. У црквеном језику именица чест значила је „част”, а част „део”. И ту су напуштена значења унета са стране. Пуризам може бити веома користан кад повећава структуралну доследност у језику, кад уклања излишне дублетне ликове појединих морфема и кад рашчишћава забуне настале из судара аутохтоног и увезеног значења истог језичког елемента. У ређим случајевима прилагођавање гласовним законима српскохрватског језика било је само филолошка играрија. Ако место љубезан кажемо тьубазан, или жртва место жертва, реч тиме не постаје разумљивија необразованом човеку, нити се боље уклапа у структуру језика, али носи ознаку да је српска, додуше видљиву само за филологе. Користи од тога нема, али нема ни штете - осим оне збрке и несигурности коју уноси свако нарушавање континуитета у језику (и правопису) код људи којима је било суђено да баш њихово поколење буде погођено променом. Ту долази до изражаја разлика између доситејевског и вуков- 
ског приступа питању књижевног језика. Доситејев аргумент био је да књижевни језик мора бити разумљив масама: „Језик има своју цену од ползе коју узрокује”. Можемо звати такав став утилитарним, или просветитељским, или хуманистичким - он је све то у исти мах. Вук је, међутим, полазио од романтичарског аксиома да је језик највидљивији и најдрагоценији израз националног бића.

Поједине речи су ипак измакле посрбљивању, иако језички стручњак у њима лако уочава трагове гласовног развоја који није српскохрватски: строг, горд, подозрив, бодар с вокалом о, искрен, устремити се, жреи, са e. Те су се речи придружиле старијем слоју позајмљеница из некадашње српске редакције црквеног језика, таквих као суштина, свештеник, општи, ревност или праведан, чији гласовни састав такође одаје њихово порекло. Сасвим је природно што су се у језику задржале и црквенословенске или руске лексеме као способан, сопственик, слог или чин, које се нису противиле правилима српскохрватског језика. Поготову су сачувани у употреби књишки изрази настали на домаћем тлу као садашъост, неверство, доказ, одбор, последииа, закључак, посада, споменик, истражити или поверење. Најзад, било је и губитака. Поједини славенизми једноставно су истиснути без замене. Значење израза као признателан, доброжелатель, препјатствовати или развратитель у савременом српскохрватском књижевном језику не може се исказати једном речју. Очигледно је тачно тврђење да Вукова језичка реформа није прошла без жртвовања извесних наслеђених вредности. Засад не располажемо списковима оваквих одбачених лексема, али и без тога је јасно да њихов број није незнатан, као што није ни превелик. Овамо се придружује и једна граматичка промена - уклањање партиципских конструкција, тог типичног изражајног инструмента књижевних језика, који реченицу чини гипкијом, а стил углађенијим. Иако партиципи не постоје у народним говорима, Вук их није изричито одбацивао, али их није ни употребљавао осим у својим најранијим делима, нити их је уврстио у своју Српску граматику. То је било довољно да Вукови епигони жигошу и истисну из језика то драгоцено средство. Заплетено је питање одговорности историјских личности за дела њихових следбеника. Али и ако прихватимо пуну Вукову кривицу за оно што је само инспирисао, и прикључимо то ненакнађеном отписивању извесног броја славенизама, ти губици свакако нису довољни да угрозе општу позитивну вредност Вукове језичке реформе. Ова тачка захтева, уосталом, продубљенију студију и прецизније закључке. То мора остати за другу прилику; тек треба да се разради научна методологија таквог поређења, које је нарочито отежано делимичном несаизмерљивошћу количини на једној и другој страни. Наравно, мора 
се имати у виду и то да је језичка реформа само један - можда прецењен - од многобројних плодова Вукове делатности. Остали резултати, пре свега реформа азбуке и правописа и спасавање народних умотворина од заборава, чисте су заслуге које нема потребе одмеравати према некаквој цени којом би биле плаћене.

У губитке спада и слабљење веза са руском културом и смањење лакоће учења руског језика. После Вука тај језик више не може лагодно служити као извор за нове речи кад год их напредак цивилизације учини потребним. Међутим, као противтежа овоме стоји уклањање разлика према књижевном језику у западним деловима српскохрватског подручја.

Вукова победа је донекле изменила дијалекатску подлогу српског књижевног језика. Војвођанска основица замењена је источнохерцеговачком. Додуше, на екавском земљишту Вукова победа је у ствари била компромис. Екавци су свој дотадашњи језик заменили вуковским, али су у њега унели екавицу. Није било услова да војвођанска и србијанска средина, које су у култури и политици биле на челу Српства, напусте своје најизразитије језичко обележје. Тако је устоличено двојство лика књижевног језика код Срба, двојство које је у исти мах богатство и извор озбиљних проблема.

Добро је познато да је Вукова победа поспешила књижевнојезичко зближавање Срба и Хрвата. Ослободивши свој књижевни језик дебелих слојева црквенословенских и руских наноса, Срби су се на тлу штокавског народног говора срели са Хрватима, који су се управо у Вуково време определили за штокавштину, одбацујући кајкавску традицију Загреба. Вуков јекавски говор био је за Хрвате прихватљивији од војвођанског екавског, а Вукове интервенције из 1836. и 1839. још су повећале ту прихватљивост. Тако је утрт пут ка бечком Књижевном договору 1850 , кад су петорица хрватских књижевника без резерве прихватили Вукова учења о језику и правопису, док је он ставио потпис под схватање илираца да су Срби и Хрвати један народ. Како учесници договора нису били изасланици својих народа, већ су се ангажовали приватно, договор није обавезивао ни Србе ни Хрвате. Ипак, он је углавном остварен: код Срба брже, победом вуковске струје, додуше без општег усвајања јекавице, а код Хрвата знатно касније, али темељније. Данас је западна варијанта књижевног језика у понеким појединостима ближа Вуку него источна. Прихватајући крајем XIX века, на нивоу гласова и граматике, вуковску верзију штокавштине, кајкавци су то учинили без остатка, док је у Србији и Војводини домаћа жива говорна штокавштина јаче утицала на књижевни језик. 